\title{
Self-Estimated Functional Inability because of Pain questionnaire for Brazilian workers with musculoskeletal pain: face and content validity
}

Questionário Self-Estimated Functional Inability because of Pain para trabalhadores brasileiros com dor musculoesquelética: validade de face e de conteúdo

El cuestionario Self-Estimated Functional Inability because of Pain destinado a trabajadores brasileños con dolor musculoesquelético: validez aparente y de contenido

Cezar Augusto Brito Pinheiro', Cid André Fidelis-de-Paula-Gomes², Vinício dos Santos Barros ${ }^{3}$, Josane Soares Pinto Melo ${ }^{4}$, Daniela Bassi-Dibai ${ }^{5}$, Almir Vieira Dibai-Filho ${ }^{6}$

\begin{abstract}
I Our study aimed to perform the face and content validity of Self-Estimated Functional Inability because of Pain (SEFIP) for workers, here called the SEFIP-work questionnaire. This is a questionnaire validity study. Our group previously translated and adapted the original version of the SEFIP, which was developed to investigate musculoskeletal pain and dysfunction to be applied to dancers (SEFIP-dance). However, due to the broad scope of the SEFIP-dance, we made changes and adaptations in the Brazilian Portuguese version of the SEFIP-dance to allow its use in workers. Therefore, face and content validity were performed for the development of the SEFIP-work based on opinions of committee of occupational disease and rehabilitation experts. After face and content validity, this SEFIP-work version was applied to 30 working individuals with musculoskeletal pain. The participants were native Brazilian Portuguese speakers aged 18 years and older. Thus, three changes were made to the questionnaire. All participants understood the SEFIP-work items and alternatives. The average total SEFIP-work score was 6.59 (SD=3.66), with the item "parte inferior das costas" (lower back) being the most marked $(n=28 ; 93.33 \%)$, with an average score of $1.18(S D=0.73)$. In conclusion, the Brazilian Portuguese version of SEFIP-work presents an acceptable level of understanding by workers in the investigation of musculoskeletal pain or discomfort.
\end{abstract}

Keywords I Pain; Reproducibility of Results; Surveys and Questionnaires.

RESUMO I Este estudo teve como objetivo verificar a validade de face e conteúdo do questionário SelfEstimated Functional Inability because of Pain (SEFIP) para trabalhadores, aqui chamado de questionário SEFIPwork. Este é um estudo de validade do questionário. Nosso grupo já traduziu e adaptou a versão original do SEFIP, que foi desenvolvido para investigar a dor musculoesquelética e disfunção a ser aplicada a dançarinos (SEFIP-dance). No entanto, devido ao amplo escopo da SEFIP-dance, fizemos mudanças e adaptações na versão traduzida e adaptada ao português brasileiro para permitir o seu uso com trabalhadores. Assim, a validade de face e conteúdo foram realizadas para o desenvolvimento do SEFIP-work baseadas em pareceres de especialistas em doenças ocupacionais e reabilitação. Após a validade de face e de conteúdo, esta versão da SEFIP-work foi aplicada a 30 indivíduos que trabalham com dor músculoesquelética. Os participantes eram falantes nativos de português brasileiro com idade igual ou superior a 18 anos. Assim, foram introduzidas três alterações no questionário. Todos os participantes entenderam os itens e alternativas da SEFIP-work. O escore total médio da SEFIP-work foi de 6,59

"Universidade Federal do Maranhão (UFMA) - São Luís (MA), Brazil. E-mail: cezarbrito.edf@gmail.com. Orcid: 0000-0002-2692-7854 2Universidade Nove de Julho (Uninove) - São Paulo (SP), Brazil. E-mail: cid.andre@gmail.com. Orcid: 0000-0001-6627-7537 3 Universidade Federal do Maranhão (UFMA) - São Luís (MA), Brazil. E-mail: viniciosantosbarros@gmail.com. Orcid: 0000-0002-8322-5824 ${ }^{4}$ Universidade Ceuma (UNICEUMA) - São Luís (MA), Brazil. E-mail: josane_pinto@hotmail.com. Orcid: 0000-0002-7444-5964 5Universidade Ceuma (UNICEUMA) - São Luís (MA), Brazil. E-mail: danielabassifisio@gmail.com. Orcid: 0000-0002-6140-0177 6Universidade Federal do Maranhão - São Luís (MA), Brazil. E-mail: dibaifilho@gmail.com. Orcid: 0000-0001-5403-8248 
(DP=3,66), com o item "parte inferior das costas" sendo o mais marcado ( $n=28 ; 93,33 \%$ ), pontuação média de 1,18 (SD=0,73). Em conclusão, a versão brasileira adaptada da SEFIP-work apresenta um nível aceitável de compreensão por parte dos trabalhadores na investigação da dor ou desconforto músculoesqueléticos.

Descritores I Dor; Reprodutibilidade dos Testes; Inquéritos e Questionários.

RESUMEN I Este estudio objetivó verificar la validez aparente y de contenido del cuestionario Self-Estimated Functional Inability because of Pain (SEFIP) destinado a trabajadores, aquí llamado cuestionario SEFIP-work. Este es un estudio sobre la validez del cuestionario. Nuestro grupo ya ha traducido y adaptado la versión original de SEFIP, que fue desarrollada para investigar el dolor musculoesquelético y su disfunción destinada a la aplicación a bailarines (SEFIP-dance). Debido al amplio alcance de SEFIP-dance, se realizó cambios y adaptaciones en la versión traducida y adaptada al portugués brasileño para permitir su aplicación a los trabajadores. Así se realizó la validez aparente y de contenido para desarrollar el SEFIP-work con base en dictámenes de expertos en enfermedades profesionales y en rehabilitación. Después de la validez aparente y de contenido, la versión de SEFIP-work se aplicó a 30 personas que trabajan con dolor musculoesquelético. Los participantes son hablantes nativos de portugués brasileño con edad igual o superior a 18 años. Se agregaron tres cambios al cuestionario. Todos los participantes entendieron los ítems y las alternativas de SEFIPwork. El promedio de la puntuación total de SEFIP-work fue de 6,59 ( $\mathrm{DE}=3,66)$, con el ítem "parte inferior de la espalda" como el más marcado ( $n=28 ; 93,33 \%$ ) y puntuación promedio de 1,18 (DE=0,73). Se concluye que la versión brasileña adaptada de SEFIP-work presenta un nivel aceptable de comprensión por parte de los trabajadores en la investigación del dolor o malestar musculoesquelético.

Palabras clave | Dolor; Reproducibilidad de los Resultados; Encuestas y Cuestionarios.

\section{INTRODUCTION}

Researchers and occupational health professionals have used different occupational health assessment instruments to implement preventive, ergonomic, and/or rehabilitation measures ${ }^{1-4}$. Most of these instruments are questionnaires and, due to their basic characteristics, are based on the measurement of variables related to the worker's own report, as in the case of pain investigation ${ }^{5,6}$.

In general, we can divide occupational health evaluation into ergonomic assessment and worker's health assessment. Within the context of ergonomics and its relationship to biomechanical risks during the execution of work tasks, the instruments commonly used for this evaluation are: Rapid Upper Limb Assessment ${ }^{1}$, Rapid Entire Body Assessment ${ }^{4}$, Quick Exposure Check ${ }^{3}$, and Rapid Office Strain Assessment ${ }^{2}$.

Regarding occupational health, several variables can be measured by questionnaires. The Need for Recovery Scale is a questionnaire that measures worker's fatigue ${ }^{7}$; the Strain Index measures risk of upper limb dysfunction ${ }^{1}$; the Maastricht Upper Extremity Questionnaire investigates arm, cervical, and shoulder involvement ${ }^{8}$. In addition to these specific instruments, there are questionnaires to measure various dimensions of pain, including the
Numerical Rating Scale ${ }^{5}$ and Örebro Musculoskeletal Pain Questionnaire 6 .

Despite the wide variety of questionnaires for workers' health, the Nordic Musculoskeletal Questionnaire (NMQ) is still the most used instrument. This instrument was developed approximately three decades ago and allows for regionalized measurement of musculoskeletal pain, i.e., considering separate body parts. Musculoskeletal pain in the NMQ is investigated at two different times: the previous 12 months and last 7 days ${ }^{9,10}$. However, the NMQlacks a severity or disability score.

In addition to and based on the NMQ, researchers developed a questionnaire to assess musculoskeletal pain in dancers entitled the Self-Estimated Functional Inability because of Pain (SEFIP-dance). The SEFIPdance also contains a disability score that ranges from 0 to 4 points, a feature that allows for a total score ${ }^{11}$. Given this context and considering the broad and generic construction of this questionnaire, our study aimed to perform the face and content validity of SEFIP for workers, here called the SEFIP-work questionnaire. Our hypothesis is that the adapted SEFIP-work questionnaire is adequately understood by the target population of our study. 


\section{METHODOLOGY}

\section{Study design}

This questionnaire validity study was conducted based on the Guidelines for the Process of Cross-cultural Adaptation of Self-Report Measures ${ }^{12}$ and Consensus-based Standards for the Selection of Health Measurement Instruments ${ }^{13}$.

Our study was conducted at the Department of Physical Education of the Universidade Federal do Maranhão (São Luís, MA, Brazil). All participants included in the study signed an informed consent form. The study participants were recruited from communities around the university by verbal invitations, posters, and social media.

\section{Adaptation of the SEFIP-work questionnaire}

Our group previously translated and adapted the original version of the SEFIP, which was developed to investigate musculoskeletal pain and dysfunction in dancers (SEFIP-dance) ${ }^{14}$. However, due to the SEFIPdance broad scope, we made changes and adaptations in the Brazilian Portuguese version to allow its use in workers (SEFIP-work). Therefore, face and content were validated in two stages for the development of the SEFIP-work ${ }^{15}$. A committee of occupational disease and rehabilitation experts was consulted to adjust or change the SEFIP-dance. This consultation provided features for the SEFIP-work to enable its application to workers.

In the first stage, four physical therapists that work in occupational disease rehabilitation were instructed to perform technical judgment, alterations, inclusion, or exclusion of items. Moreover, these four physical therapists were asked to give their opinion on the ability of the SEFIPwork to measure musculoskeletal-pain-related disability.

In the second stage, four healthcare professionals were consulted to verify possible difficulties in reading the questionnaire, clarity of response alternatives, presence of typographical errors, font size, level of understanding of items, length, application time, and overall evaluation.

We have adopted the following inclusion criteria for physical therapists: working with occupational health for at least 24 months; be native and fluent in Brazilian Portuguese; be available for meetings and consultations to clarify the opinion issued. For healthcare professionals (two physical therapists and two physical education professionals), we adopted the following inclusion criteria: prior experience using questionnaires in patient assessment; be Brazilian and speak Brazilian Portuguese as mother tongue; be available for meetings and consultations to clarify the opinion issued.

After face and content validation, with $100 \%$ of agreement of the experts, the pre-final SEFIP-work version was established and applied to 30 workers with musculoskeletal pain. The participants were aged 18 years and older with Brazilian Portuguese as their mother tongue. Participants answered the questionnaire and established their understanding of the pre-final version of the SEFIPwork by ticking "yes" or "no" for each item. An item understood by less than $20 \%$ of the participants would be changed and retested in a new sample of 30 participants until the achievement of the desired understanding level ${ }^{12,13}$. This procedure established the final version of the SEFIPwork in the Brazilian Portuguese.

\section{SEFIP-work score}

The questionnaire consists of 14 items, each item related to a body part. There are five answers for each item, with scores that range from 0 to 4 . Thus, the total score varies between 0 and 56 points; the higher the score, the higher disability ${ }^{11}$. In addition to this total score, we suggest estimating a separate score for each body region to produce a score from 0 (no disability) to 4 (maximum disability). This regionalized score avoids errors in interpreting the magnitude of disability that can be generated by pure analysis of the total score.

\section{Statistical analysis}

Descriptive analysis was performed; qualitative variables are presented as absolute numbers (percentage) and quantitative variables as means (standard deviation[SD]). Data processing was performed using SPSS software version 17.0 (Chicago, IL, USA).

\section{RESULTS}

After face and content validation, three changes were made to the questionnaire: the answer associated with score 4 was changed from "Não consigo dançar por causa $d a$ dor" (I cannot dance because of the pain) to "Não consigo trabalhar por causa da dor" (I cannot work because of the pain); item 13 was changed from "Tornozelos/pés" (ankles/ feet) to "Tornozelos" (ankles), item 14 was changed from "Dedos dos pés" (toes) to "Pés" (feet). 
Therefore, this version subjected to the face and content validity was considered the pre-final SEFIP-work version. Thirty workers that spoke Brazilian Portuguese as mother tongue answered the questionnaire. The average age of participants was 34.76 years $(\mathrm{SD}=6.84)$; $20(66.66 \%)$ participants were men. Table 1 shows other personal and worker characteristics.

Table 1. Personal and occupational characteristics of study participants

\begin{tabular}{|c|c|}
\hline Variables & $\mathrm{n}(\%)$ or mean (standard deviation) \\
\hline Age (years) & $34.76(6.84)$ \\
\hline Gender (male) & $20(66.66 \%)$ \\
\hline Height (kg) & $65.44(9.94)$ \\
\hline Weight (m) & $1.69(0.07)$ \\
\hline Body mass index $\left(\mathrm{kg} / \mathrm{m}^{2}\right)$ & $22.84(2.45)$ \\
\hline \multicolumn{2}{|l|}{ Marital status } \\
\hline Single & $10(33.33 \%)$ \\
\hline Married & $13(43.33)$ \\
\hline Divorced & $7(23.34 \%)$ \\
\hline \multicolumn{2}{|l|}{ Schooling } \\
\hline Middle school & $5(16.67 \%)$ \\
\hline High school & $17(56.66 \%)$ \\
\hline Higher education & $8(26.67 \%)$ \\
\hline Physical activity (yes) & $25(83.33 \%)$ \\
\hline \multicolumn{2}{|l|}{ Occupation } \\
\hline Teacher & $4(13.33 \%)$ \\
\hline Cleaner & $15(50 \%)$ \\
\hline Engineer & $2(6.67 \%)$ \\
\hline Administrator & $2(6.67 \%)$ \\
\hline Driver & $4(13.33 \%)$ \\
\hline Others & $3(10 \%)$ \\
\hline Time in the same job (months) & $58.27(81.32)$ \\
\hline Weekly working (hours) & $38.09(7.36)$ \\
\hline \multicolumn{2}{|l|}{ Posture at work } \\
\hline Standing & $8(26.67 \%)$ \\
\hline Sitting & $6(20 \%)$ \\
\hline Standing/sitting & $16(53.33 \%)$ \\
\hline
\end{tabular}

(continues)
Table 1. Continuation

\section{Variables}

$\mathrm{n}(\%)$ or mean (standard deviation)

Professional gesture type

Manual

$22(73.33 \%)$

Manual/non-manual

$8(26.67 \%)$

All participants understood the SEFIP-work items and alternatives, and thus no changes in the pre-final phase were necessary. The average total SEFIP-work score was 6.59 ( $\mathrm{SD}=3.66)$, with the item "parte inferior das costas" (lower back) being the most marked ( $\mathrm{n}=28$; 93.33\%), with an average score of 1.18 ( $\mathrm{SD}=0.73)$. Table 2 shows further details on the results of functional disability and pain measured by SEFIP-work. Figures 1 and 2 show the final version of the SEFIP-work questionnaire in Brazilian Portuguese and English, respectively.

Table 2. Total score and body region score of Self-Estimated Functional Inability because of Pain (SEFIP-work) in study participants

\begin{tabular}{llr}
\multicolumn{1}{c}{ SEFIP-work item } & \multicolumn{1}{c}{$\begin{array}{c}\text { Mean (standard } \\
\text { deviation) }\end{array}$} \\
Pescoço & Neck & $0.77(0.68)$ \\
Ombros & Shoulders & $0.54(0.59)$ \\
Cotovelos & Elbows & $0.13(0.35)$ \\
Punhos/mãos & Wrists/hands & $0.68(0.56)$ \\
Parte superior das costas & Upper back & $0.87(0.73)$ \\
Parte inferior das costas & Lower back & $1.18(0.73)$ \\
Quadris & Hips & $0.13(0.46)$ \\
Coxas (frente) & Thighs (front) & $0(0)$ \\
Coxas (atrás) & Thighs (back) & $0.18(0.39)$ \\
Joelhos & Knees & $0.36(0.58)$ \\
Pernas (frente) & Legs (front) & $0(0)$ \\
Panturrilhas & Calves & $0.27(0.55)$ \\
Tornozelos & Ankles & $0.63(0.72)$ \\
Pés & Feet & $0.86(0.83)$ \\
Escore total & Total score & $6.59(3.66)$
\end{tabular}


Self-Estimated Functional Inability because of Pain (Trabalho)

Nome: Data:

Você está sentindo qualquer dor ou desconforto muscular agora? Se sim, indique abaixo até que ponto isso afeta sua atividade profissional. Por favor, marque um quadrado para cada região do corpo.

\begin{tabular}{|c|c|c|c|c|c|}
\hline & Sem dor & $\begin{array}{l}\text { Alguma dor, mas sem } \\
\text { muitos problemas }\end{array}$ & $\begin{array}{l}\text { Bastante dor, mas eu } \\
\text { consigo suportar }\end{array}$ & $\begin{array}{l}\text { Muita dor, eu evito } \\
\text { certos movimentos }\end{array}$ & $\begin{array}{l}\text { Não consigo trabalhar } \\
\text { por causa da dor }\end{array}$ \\
\hline & (0) & (1) & (2) & (3) & (4) \\
\hline Pescoço & 무 & $\square$ & $\square$ & $\square$ & $\square$ \\
\hline Ombros & ㅁ. & $\square$ & $\square$ & $\square$ & ㅁ. \\
\hline Cotovelos & $\square$ & $\square$ & $\square$ & $\square$ & $\square$ \\
\hline Punhos/mãos & ㅁ. & $\square$ & ㅁ. & ㅁ. & $\square$ \\
\hline Parte superior das costas & $\square$ & $\square$ & $\square$ & $\square$ & $\square$ \\
\hline Parte inferior das costas & $\square$ & $\square$ & $\square$ & $\square$ & ㅁ. \\
\hline Quadris & 口 & 口 & 口 & 口 & 口 \\
\hline Coxas (frente) & $\square$ & $\square$ & ㅁ. & ㅁ.. & ㅁ. \\
\hline Coxas (atrás) & ㅁ. & $\square$ & a & ㅁ. & ㅁ. \\
\hline Joelhos & ㅁ. & $\square$ & ㅁ. & ㅁ. & ㅁ. \\
\hline Pernas (frente) & ㅁ. & $\square$ & ㅁ. & $\square$ & ㅁ. \\
\hline Panturrilhas & ㅁ. & ㅁ & ㅁ & ㅁ. & ㅁ. \\
\hline Tornozelos & ㅁ & $\square$ & ㅁ... & ㅁ. & ㅁ... \\
\hline Pés & ㅁ & ㅁ & ㅁ & ㅁ. & ㅁ. \\
\hline
\end{tabular}

Figure 1. Brazilian Portuguese version of Self-Estimated Functional Inability because of Pain for workers (SEFIP-work)

Self-Estimated Functional Inability because of Pain (Work)

Name: Date:

Are you feeling any muscle pain or discomfort now? If so, indicate below how much it affects your professional activity. Please check one box for each body region.

\begin{tabular}{|c|c|c|c|c|c|}
\hline & No pain & $\begin{array}{c}\text { Some pain, but without } \\
\text { many problems }\end{array}$ & $\begin{array}{l}\text { Quite a bit of pain, } \\
\text { but I can handle it }\end{array}$ & $\begin{array}{l}\text { A lot of pain, I avoid } \\
\text { certain moves }\end{array}$ & $\begin{array}{c}\text { I cannot work } \\
\text { because of the pain }\end{array}$ \\
\hline & $(0)$ & (1) & $(2)$ & (3) & (4) \\
\hline Neck & $\square$ & $\square$ & $\square$ & $\square$ & $\square$ \\
\hline Shoulders & $\square$ & $\square$ & $\square$ & $\square$ & $\square$ \\
\hline Elbows & $\square$ & $\square$ & $\square$ & $\square$ & $\square$ \\
\hline Wrists/hands & $\square$ & $\square$ & $\square$ & $\square$ & $\square$ \\
\hline Upper back & $\square$ & $\square$ & $\square$ & $\square$ & $\square$ \\
\hline Lower back & $\square$ & $\square$ & $\square$ & $\square$ & $\square$ \\
\hline Hips & $\square$ & $\square$ & $\square$ & $\square$ & $\square$ \\
\hline Thighs (front) & $\square$ & $\square$ & $\square$ & $\square$ & $\square$ \\
\hline Thighs (back) & $\square$ & $\square$ & $\square$ & $\square$ & $\square$ \\
\hline Knees & $\square$ & $\square$ & $\square$ & $\square$ & $\square$ \\
\hline Legs (front) & $\square$ & $\square$ & $\square$ & $\square$ & $\square$ \\
\hline Calves & $\square$ & $\square$ & $\square$ & $\square$ & $\square$ \\
\hline Ankles & $\square$ & $\square$ & $\square$ & $\square$ & $\square$ \\
\hline Feet & $\square$ & $\square$ & $\square$ & $\square$ & $\square$ \\
\hline
\end{tabular}

Figure 2. English version (free translation) of Self-Estimated Functional Inability because of Pain for workers (SEFIP-work) 


\section{DISCUSSION}

We performed the face and content validity of the SEFIP-work questionnaire for Brazilian workers. This process is the first step in the validation process of this questionnaire, and it will allow its future use to investigate musculoskeletal injuries in this population.

The process of initial validity is usually published as the basis for future studies that focus on the analysis of psychometric properties. In this sense, the methods and objectives of our study are similar to the investigations conducted by Kamonseki, Fonseca and Calixtre ${ }^{16}$, Donat et al. ${ }^{17}$, and De Bortoli et al. ${ }^{18}$. Our study and these investigations ${ }^{16-18}$ were mainly based on the classics publications of Beaton et al. ${ }^{12}$ and Prinsen et al. ${ }^{13}$.

According to a previous study ${ }^{19}$, the understanding of a questionnaire by $80 \%$ of the sample included in the pre-final testing phase is acceptable. In our study, $100 \%$ of the sample comprehended all SEFIP-work items, statements, and instructions. This result was expected for the questionnaire due to the simple presentation, straight forward structure, and absence of long and interpretive sentences.

"Lower back", followed by "upper back", were the regions with the highest prevalence of musculoskeletal pain. Our sample consisted of workers from various professional fields. Using $\mathrm{NMQ}_{2}$ other studies also investigated pain distribution in workers and found similar results: Akodu and Ashalejo ${ }^{20}$ identified a greater presence of lower back pain in hospital nurses, LópezGonzález, González and González-Menéndez ${ }^{21}$ found the highest presence of pain in the neck region of laboratory technicians, and Özdinç et al. ${ }^{22}$ observed higher prevalence of pain in the neck and lumbar region of scholars.

Our study has some limitations. Although face and content validity is the first step in the validation process, it alone does not support research or occupational use. Thus, future studies should measure the psychometric properties of the SEFIP-work in Brazilian Portuguese. Moreover, we recommend the translation the SEFIP-work questionnaire and its adaptation to other languages. We present in our article an English version of the SEFIPwork (Figure 2); however, it has been freely translated. Thus, textual revisions and cross-cultural adaptations must be performed by researchers that speak English as mother tongue. Finally, we include workers from different professional categories, which makes the sample heterogeneous. This fact must be considered when interpreting the results presented here.

\section{CONCLUSION}

The Brazilian Portuguese version adapted of SEFIP-work presents an acceptable level of understanding by workers in the investigation of musculoskeletal pain or discomfort.

\section{REFERENCES}

1. Valentim DP, Sato TO, Comper MLC, Silva AM, Boas CV, Padula RS. Reliability, Construct Validity and Interpretability of the Brazilian version of the Rapid Upper Limb Assessment (RULA) and Strain Index (SI). Braz J Phys Ther. 2018;22(3):198-204. doi:10.1016/j.bjpt.2017.08.003

2. Rodrigues MS, Sonne M, Andrews DM, Tomazini LF, Sato TO, Chaves TC. Rapid office strain assessment (ROSA): Cross cultural validity, reliability and structural validity of the Brazilian-Portuguese version. Appl Ergon. 2019;75:143-54. doi: 10.1016/J.APERG0.2018.09.009

3. Comper MLC, Costa LOP, Padula RS. Quick Exposure Check (QEC): a cross-cultural adaptation into Brazilian-Portuguese. Work. 2012;41 Suppl 1:2056-9. doi: 10.3233/WOR-2012-0430-2056

4. Lamarão AM, Costa LCM, Comper MLC, Padula RS. Translation, cross-cultural adaptation to Brazilian-Portuguese and reliability analysis of the instrument Rapid Entire Body Assessment-REBA. Braz J Phys Ther. 2014;18(3):211-7. doi: 10.1590/bjpt-rbf.2014.0035

5. Ferreira-Valente MA, Pais-Ribeiro JL, Jensen MP. Validity of four pain intensity rating scales. Pain. 2011;152(10):2399-404. doi: 10.1016/j.pain.2011.07.005

6. Fagundes FRC, Costa LOP, Fuhro FF, Manzoni ACT, Oliveira NTB, Cabral CMN. Örebro Questionnaire: short and long forms of the Brazilian-Portuguese version. Qual Life Res. 2015;24(11):2777-88. doi: 10.1007/s11136-015-0998-3

7. Moriguchi CS, Alem MER, van Veldhoven M, Coury HJCG. Cultural adaptation and psychometric properties of Brazilian Need for Recovery Scale. Rev Saude Publica. 2010;44(1):131-139. doi: 10.1590/S0034-89102010000100014

8. Turci AM, Bevilaqua-Grossi D, Pinheiro CF, Bragatto MM, Chaves TC. The Brazilian Portuguese version of the revised Maastricht Upper Extremity Questionnaire (MUEQ-Br revised): translation, cross-cultural adaptation, reliability, and structural validation. BMC Musculoskelet Disord. 2015;16(1):41. doi: 10.1186/s12891-015-0497-2

9. Kuorinka I, Jonsson B, Kilbom A, Vinterberg H, Biering-Sørens F, Andersson G, Jørgensen K. Standardised Nordic questionnaires for the analysis of musculoskeletal symptoms. Appl Ergon. 1987;18(3):233-37. doi: 10.1016/0003-6870(87)90010-x

10. Dickinson CE, Campion K, Foster AF, Newman SJ, O'Rourke AM, Thomas PG. Questionnaire development: an examination of the Nordic Musculoskeletal questionnaire. Appl Ergon. 1992;23(3):197-201. doi: 10.1016/0003-6870(92)90225-k

11. Ramel E, Moritz U, Jarnlo G. Validation of a pain questionnaire (SEFIP) for dancers with a specially created test battery. Med Probl Perform Art. 1999;14(4):196-203.

12. Beaton DE, Bombardier C, Guillemin F, Ferraz MB Guidelines for the Process of Cross-Cultural Adaptation of Self-Report Measures. Spine. 2000;25(24):3186-91. doi: 10.1097/00007632-200012150-00014 
13. Prinsen CAC, Mokkink LB, Bouter LM, Alonso J, Patrick DL, de Vet HCW, Terwee CB. COSMIN guideline for systematic reviews of patient-reported outcome measures. Qual Life Res. 2018;27:1147-57. doi: 10.1007/s11136-018-1798-3

14. Reis-Júnior JR, Protázio JB, Muribeca-de-Castro AM, Pinheiro JS, Takahasi HY, Pires FO. Brazilian version of the Self-Estimated Functional Inability because of Pain questionnaire for musculoskeletal injuries relating to dance and sport: translation and cross-cultural adaptation. Sao Paulo Med J. 2020;138(1):11-8. doi: 10.1590/1516-3180.2019.0375.r1.08102019

15. De Groef A, Van Kampen M, Moortgat P, Anthonissen M, Van den Kerckhove, Christiaens M-R, et al. An evaluation tool for Myofascial Adhesions in Patients after Breast Cancer (MAP-BC evaluation tool): concurrent, face and content validity. PLoS One. 2018;13(3):e0193915. doi: 10.1371/journal.pone.0193915

16. Kamonseki DH, Fonseca CL, Calixtre LB. The Brazilian version of the Bournemouth questionnaire for low back pain: translation and cultural adaptation. Sao Paulo Med J. 2019;137(3):262-9. doi: 10.1590/1516-3180.2018.0482120419

17. Donat JC, Lobo NS, Jacobsen GS, Guimarães ER, Kristensen $\mathrm{CH}$, Mendlowicz MV, et al. Translation and cross-cultural adaptation of the International Trauma Questionnaire for use in Brazilian Portuguese. Sao Paulo Med J. 2019;137(3):270-7. doi: 10.1590/1516-3180.2019.0066070519

18. De Bortoli PS, Jacob E, Castral TC, Santos CB, Fernandes AM, Nascimento LC. Cross-cultural adaptation of the adolescent pediatric pain tool for Brazilian children and adolescents with cancer. Texto Contexto Enferm. 2019;28:e20160108. doi: 10.1590/1980-265x-tce-2016-0108

19. da Silva Rodrigues EK, de Cássia Registro Fonseca M, MacDermid JC. Brazilian version of the Patient Rated Wrist Evaluation (PRWE-BR): cross-cultural adaptation, internal consistency, test-retest reliability and construct validity. J Hand Ther. 2015;28(1):69-76. doi: 10.1016/j.jht.2014.09.008

20. Akodu AK, Ashalejo ZO. Work-related musculoskeletal disorders and work ability among hospital nurses. J Taibah Univ Med Sci. 2019;14(3):252-61. doi: 10.1016/j.jtumed.2019.02.009

21. López-González MJ, González S, González-Menéndez E. Prevalence of musculoskeletal problems in laboratory technicians. Int J Occup Saf Ergon. 2019;25:1-12. doi: 10.1080/10803548.2019.1646531

22. Özdinç S, Kayabınar E, Özen T, Turan FN, Yılmaz S. Musculoskeletal problems in academicians and related factors in Turkey. J Back Musculoskelet Rehabil. 2019;32(6):1-7. doi: 10.3233/BMR-181171 